\title{
ARTICLES
}

\section{Parents, Pay Attention! \\ Factors Related to Parental Involvement with Education in Northern Uganda}

\author{
Betty Akullu Ezati, \\ College of Education \& External Studies, \\ Makerere University, bezati@cees.mak.ac.ug \\ Jody L. McBrien, \\ School of Education, \\ University of South Florida, Sarasota-Manatee ilmcbrien@sar.usf.edu \\ Jan Stewart, \\ Faculty of Education, \\ University of Winnipeg, Ja.stewart@uwinnipeg.ca \\ Cornelius Ssempala, \\ College of Education \& External Studies, \\ Makerere University, cssempala@cees.mak.ac.ug \\ Peter Ssenkusu, \\ College of Education \& External Studies, \\ Makerere University, pssenkusu@cees.mak.ac.ug
}

\begin{abstract}
Prior to the colonial period (1896-1962), education of children in Uganda was a family responsibility. The introduction of formal Britishstyled schooling disrupted traditional learning by changing the nature of lessons into formal, Western style classrooms and lectures and by placing educational responsibility into the hands of missionaries, teachers, and the government. Since Uganda gained political independence in 1962, education and parental participation in their children's education have been further disrupted by numerous civil wars and resulting displacement, poverty, trauma, and government policies. The purpose of this article is to explore the relationship between historical effects and parental responses to education in northern Uganda. The authors used findings in the literature along with results from three research periods between 2007-2015 during
\end{abstract}


which parents, teachers, and community leaders were interviewed in focus groups or individually, to understand ways in which parents were involved in or withdrawn from their children's education, and reasons for their involvement or inactivity. The authors draw from Epstein and Saunders' (2006) framework for involvement and Bronfenbrenner's (1979, 1999) ecological systems theory to frame the research. Our research indicates that a complexity of factors has contributed to reduced parental involvement, including poverty, dislocation, fear, alcohol consumption, and misunderstanding of policy. We conclude with some suggestions for improvement.

\section{Introduction}

This article examines the extent to which parents in northern Uganda have engaged with schools in the education of their children, with a particular emphasis on the Lord's Resistance Army (LRA) war years to the present. We also consider how an ecological approach might enhance educational success (Bronfenbrenner, 1979, 1999). Specifically, our work explores the following questions:

1. What factors have influenced parental involvement in education in Northern Uganda?

2. In what ways might an ecological approach enhance academic achievement?

After a justification of the importance of education in post-conflict areas and of parent involvement, we describe our theoretical frameworks and methods. We proceed by combining our research with a literature review that contextualises events and provides explanations about education and parental involvement in Uganda from pre-colonial times through the beginnings of the LRA war and the 1996 Universal Primary Education (UPE) policy to the present.

\section{Significance}

Education is considered an important instrument in the reduction of societal violence (Davies, 2004; Woolman, 2001). It can provide a sense of hope and stability to war returnees and the wider community through provisions of knowledge, values, competencies, attitudes, and behaviours that encourage respect for human dignity and diversity. Education can increase the capacity of the younger generation to build a better future and learn new ways to live together. As Bird (2003) explained, schooling is one 
of the best methods to support the healing of psychosocial trauma for children and can play a critical role in their return to normal life. The International Network for Education in Emergencies (INEE, 2010) noted that education can give children the opportunity to develop life-saving skills, bring shape and structure to their lives, and provide protection against exploitation and harm. Machel (2001) concluded that educational development must be dedicated to addressing the traumatic impact of war on children in order to establish a sustainable future. Suzuki's (2010) research in Uganda's Mukono District concluded that parental participation in a Ugandan context involves collective support for school financing, building, and decision-making (p. 243).

Although parent participation is emphasised in all situations, in emergencies such as civil unrest, war, and post-conflict rebuilding it is even more important as it augments social cohesion between schools and community: "Creating local parent-teacher associations, or parent support groups, increase(s) the social glue ('bonding' social capital) and thus build(s) community” (Burde, 2004, p. 75).

\section{Theoretical Contexts}

Epstein and Saunders (2006) outlined six types of parental-school involvement opportunities that have been shown to promote productive engagement. These include:

- Parenting - parents' expectations and attitudes regarding education.

- Communicating - communication between home and school regarding school program and student progress.

- Volunteering — parental help during school events or activities (e.g. field trips, concerts, sports teams).

- Learning at home-monitoring and assisting with school-related tasks (e.g. homework); registration in extracurricular academic or arts programs.

- Decision-making - involvement in a parent-teacher organisation or higher-level educational committee.

- School and parent collaborations with the community.

Although these researchers examine parent involvement from a Western perspective, the points that they highlight have also been found to be important in African contexts (Burde, 2004; Tripp, 2000; Woolman, 2001). What they lack, however, is a connection with the governmental bodies of Uganda. Such regard is considered critical in maintaining broad participation in educational goals (Lewis \& Naidoo, 2004). 
Effective learning takes place when parents, pupils, and teachers are in touch. These interactions correspond to several levels of Urie Bronfenbrenner's (1979, 1999) early and late theories of ecological systems. Bronfenbrenner's theory helps to explain how a child's development relies on interdependent relationships in various levels of the child's social environment, from the most intimate to the most distant of social systems. He explains them as follows:

- Microsystem - most direct contacts of the child: family, friends, teachers

- Mesosystem -interactions between microsystems: relationships between parents and teachers, peer groups and neighbourhoods, church and home

- Exosystem - social institutions: government agencies, school systems, mass media

- Macrosystem - political, cultural, social structures: values, laws, customs

- Chronosystem - historical time and events

Although our research concentrates on the first two levels, it is important to note the effects brought on by other spheres of influence. For instance, political decisions will demonstrate causes for reduced parental involvement at the exosystem and macrosystem levels. Obviously, war had calamitous effects on education; thus, the chronosystem is of great importance in affecting children and families. Additionally, his later work (1999) emphasised the interrelationship between processes, persons, contexts, and time. Together, Epstein and Saunders' (2006) framework and Bronfenbrenner's $(1979,1999)$ theory provide insights by which parental involvement behaviours may be analysed and evaluated.

\section{Methods}

This article draws upon data from three research periods conducted in northern Uganda between 2007-2008, 2010-2011, and 2012-2015. In total, 225 people - teachers, students, parents, and community leaders participated, although the individuals were not necessarily the same throughout the years. In 2007, a ceasefire was in place and peace talks began. The environment was, however, still characterised by fear and doubt, and many families remained in camps (set up by the government during the conflict for internally displaced people). We collected data from four purposively selected camps: Obim (Lira district), Palenga, Unyama and Alokolum (Gulu district). These camps were selected based on 
members of our research team who are Ugandan and had information and contacts with these camps. In addition, these camps were safe to travel to without army escort. From each camp two schools were selected based on willingness of administrators to participate in the study. The samples included head teachers, teachers, parents, administrators, students, and community leaders (See Table One).

By 2010, the majority of camps had closed, and most schools had returned to their original locations. We collected data from schools whose administrators agreed to participate in their original settings. Schools that were set up for the rehabilitation of war returnees were included. The sample included the same stratification of participants; only the setting had changed, and the numbers were fewer. The final data collection resulted from one of the author's extended research in Lira and Gulu, which increased by 80 the number of teachers, parents, community leaders, and students as participants. The studies were approved by an Internal Review Board for human subjects at the University of South Florida and the University of Winnipeg.

\section{Table 1: Participants}

\begin{tabular}{|l|r|r|r|r|}
\hline Participants & 2007 & 2012 & 2014 & Total \\
\hline Teachers & 36 & 13 & 24 & $\mathbf{7 3}$ \\
\hline $\begin{array}{l}\text { School Administrators / District Education } \\
\text { Officers }\end{array}$ & 14 & 11 & 4 & $\mathbf{2 9}$ \\
\hline Students & 15 & 15 & 15 & $\mathbf{4 5}$ \\
\hline Parents & 14 & 18 & 10 & $\mathbf{4 2}$ \\
\hline Community/NGO Leaders & 12 & 14 & 10 & $\mathbf{3 6}$ \\
\hline
\end{tabular}

In previous studies, we have reported findings with Ugandan students (McBrien, Ezati, \& Stewart, 2015; McBrien, Stewart, \& Ezati, in press; Stewart, McBrien, \& Ezati, in press). In this article, we concentrate on the findings with adults. To conduct this qualitative study, we used semistructured protocols for individual and focus group interviews, and rather than pre-determining codes, we looked for evolving codes based on repeated information found in the interviews (Strauss \& Corbin, 1990). These repetitions are what we used for themes discussed in the findings.

We limited the study primarily to participants who could communicate in English. This creates a limitation in the study, as some occupants in the northern districts are not fluent in English. However, given that Uganda was a British colony, and the language of instruction is English, the majority of those we wanted to interview spoke English. The primary exceptions were parents. In a few cases, we had an acquaintance of a parent 
translate. However, in most cases, we interviewed English-speaking participants. We used digital recorders and transcribed interviews. To provide checks for our transcriptions, we asked northern Ugandan teachers to transcribe portions of the recorded interviews to insure accuracy.

To maintain anonymity for participants, we used simple code identifiers: Parent A, Parent B, Teacher A, etc. Themes are presented in Table 2, which were quantified from the first two periods of research. Interviews from the third period of research, though not quantified, do not indicate reasons to consider significant change to these findings.

\section{Education Amidst Colonisation, War, and Rebuilding}

Prior to British colonialism, parents and elders took responsibility for children's education, in the form of storytelling, dance, and song (Kia \& Aceng, 2015; Stewart, Kuly, Ezati, \& McBrien, 2015). The purpose of instruction was to create social harmony, perpetuate cultural values, develop character, and provide work and life skills (Muyanda-Mutebi, 1996).

During the years of British colonialism, both Anglican and Catholic missionaries promoted education, with little regulation by the colonial government (Muyanda-Mutebi, 1996). Most students were children of chiefs and other prominent families. The curriculum led to a preference for Western and Christian values over students' own indigenous cultures. Tripp (2004) observed, "The implicit racism and sense of hierarchy of missionary teachers has been shown to serve the broader colonial project” (p. 125).

Following independence, the National Institute of Education at Makerere University took responsibility for curriculum that included the goals of national unity, guaranteeing human rights, upholding national independence, promoting ethical citizen values and democratic institutions (National Curriculum Development Centre Act, 1973). The Act has no mention of parents, nor is there a place for a parent on the Academic Steering Board, further taking responsibility away from parents. In addition, Uganda experienced a number of civil wars in its post-colonial period, beginning in 1966, and including unrest in the 1980s in the Central region, West Nile region (1980s-1990s), Eastern region (1990), Western region (late 1990s), and northern Uganda, the primary focus of this article (1986 2008). So much war has caused disruption to family life, civil society, jobs, and education.

Rebel groups in northern Uganda trace their origin to the Uganda People's Democratic Army (UPDA), a dissident group of the Uganda National Liberation Army (UNLA) that was ousted by Museveni's National 
Resistance Army (NRA) and fled to Sudan. In 1986, Joseph Kony, leader of the Lord's Resistance Army (LRA), sustained a protracted rebellion that resulted in over 20 years of civil war during which thousands of lives were lost and 1.5 million people of Northern Uganda displaced (Human Rights Watch, 2003; for more details on the wars and rebel leaders, see McCormac \& Benjamin, 2008). In 2003 the UN's Undersecretary General for Humanitarian Affairs affirmed the LRA war to be one of the worst global humanitarian crises (Dolan \& Hovil, 2006). The Women's Commission (2001) estimated that by 2001, the LRA had abducted 28,000 children, and that 80 percent of LRA soldiers were children. Children and adults were beaten into submission to serve as LRA soldiers, threatened with death if they escaped, and forced to fight against the UPDF. Children were forced to beat, club, or trample to death other children and adults who attempted to escape (Lexow \& Ngonzi, 2008). Young girls were made to work for long hours fetching water and firewood, gathering food and performing domestic duties for LRA commanders. They were also subjected to sexual violence and rape, and thus were exposed to the risk of being infected with diseases including HIV/AIDS. By the end of 2002, there were still 800,000 internally displaced persons (IDPs), or approximately 70 percent of the population of affected northern regions in IDP camps (Human Rights Watch, 2003). The combination of violence, killing, massive human displacement, and destruction to the society and economy created a complex emergency, as defined by the Inter-Agency Standing Committee (IASC, 2008, p. 8). The country was also considered a 'fragile state,' defined as one having 'a limited capacity and/or will to provide basic services to the population' (OECD-DAC, 2008, in INEE, 2011; McCormac \& Benjamin, 2008).

Fearing abduction and death, approximately 95 per cent of the people in Kitgum, Gulu, Pader, and Lira regions moved to IDP camps during the war (Human Rights Watch, 2005). Others stayed in their homes, but their children travelled each night to and from the nearest urban centres or camps before returning home again each morning in an effort to avoid capture by the LRA. An estimated 45,000 children were among these 'night commuters' (Ezati, Ssempala, \& Ssenkusu, 2011; Women's Commission, 2001). Regardless of where they stayed, the population experienced many challenges. The camp huts were overcrowded and characterised by poor sanitation facilities, disease, lack of social infrastructure, food shortages, and high malnutrition rates. The night commuters were vulnerable to theft, sexual assault, and other abuses from either thugs or even some army soldiers. The war eroded security and kept people in perpetual fear of 
destruction (Human Rights Watch, 2003), changing the social fabric of northern Ugandan society. The Ministry of Education and Sport observed that in 2007, a quarter million of children over the age of 10 had lost one or both parents, and about that same amount of children had received no education at all (UNICEF, 2009). A loving and caring environment, which is essential for normal child upbringing, was not readily available in a context where children lost parents or guardians and were themselves targeted for recruitment into rebel forces. Parent A stated,

I am a parent in this school but also a local leader. It is true the war has done a lot of damage towards children's development because culturally we used to have our cultural mechanisms of giving informal education, care and support also with the help of other relatives. When war came that arrangement was destroyed - we have a lot of orphans- although they were taken care of by relatives, today those children are left alone because their parents were killed.

To make education in IDP camps possible, numerous local schools were brought together under one school or 'learning centre' (Ezati, Ssempala, \& Ssenkusu, 2011), which resulted in many different schools being combined into one school in each IDP camp. Consequently, parents no longer had a say regarding which kind of school their children attended. This loss of autonomy undermined parental authority. These centres were characterised by overcrowding, with very high teacher-pupil ratios. For example, although the government standard ratio of children per teacher was 50:1 in Kitgum and Gulu, the actual ratio was 150-300:1 in camps (Women's Commission, 2001). Such overcrowding not only affected the quality of interactive learning and teachers' ability to motivate learners, but also exhausted the teachers. The situation was more difficult in boarding schools, where teachers assumed the role of being 'parents' to the pupils that they taught. Giving instructions in this climate of fear, instability, and lack of resources made it nearly impossible for teachers to create an environment conducive to learning.

\section{Factors affecting Loss of Parental Authority and Involvement}

\section{Poverty}

Factors contributing to a reduction in northern Ugandan parental involvement in education are complex and overlapping: increased poverty, 
fears for their children's safety, increased alcohol consumption, loss of autonomy, and disconnection between changing policies and cultural traditions. Prior to the LRA war, parents met financial obligations at schools, if only for their eldest male child, through small-scale agriculture. However, during the war, farmland was abandoned as citizens had to flee for their lives While the majority of families were displaced into camps their cattle were lost either to the rebels or to other cattle-rustlers (McCormac \& Benjamin, 2008). Few parents could provide scholastic materials and uniforms for their children. With relatively little time to prepare, people found themselves in IDP camps, being looked after by external donors for most of their needs. As Higgins (2009) reported, 70\% of the people in northern Uganda survived on hand outs and 95\% lived in desperate poverty.

Head Teacher A in our study reported that many children had to work in order to earn money that would sustain them in the schools. Thus, the respect that parents used to command as providers for their children declined. Head Teacher A explained the lowering of parental commitment thus:

Before the war, parents used to participate in school activities like building teachers' houses and contributing to capital development. During the war, their contribution became very minimal since the majority of them were not involved in meaningful employment while some seemed to attach less value to the school.

In both interviews and focus groups, many parents agreed that warcreated poverty diminished their parental authority and caused their families to be dependent on the World Food Bank programme and other NGOs. A father (Parent B) stated, "We used to own cattle before the war, and we could sell some cattle to clear their children's fees. But because of this war all our cattle were taken away, which made us to be very helpless." In a separate interview, Parent $C$ concurred, saying:

Before the war we had the ability to feed our children - even if children did not eat food at school, they would get something to eat at home after school. During the war most times we as parents could not feed the children and it turned out to be a duty of the school. That is how we lost control of our children. Whenever the kids saw the WFP trucks, they would 
run after them - they would say the food has come, they could not imagine that food could be grown at home by their parents.

Parent D stated, "Parents became relaxed since their children were being fed at school. Some of the children had only one meal a day that was the one served at school."

\section{Fear}

At the beginning of the war, parents feared to send their children to schools, especially before the establishment of IDP camps, as schools had become recruiting grounds for rebels. The situation was worse for the girls. When the war was at its peak, parents did not send their girls to school as they feared they would be abducted. Parent E remarked,

In most cases parents made sure that their daughters got married or were impregnated so that rebels would not abduct them. Rebels never wanted to abduct married girls as they believed that they were already infected by HIV and AIDS.

Head Teacher B concurred, stating,

Some parents married off their daughters between the years 12 to 14 so that they could not be abducted. Rebels never wanted married girls because they were believed to have AIDS. As a result, during the war period district schools had a very low number of girls, especially in the upper section, as compared to municipal schools.

In the camps, parents perceived that their children were safer, although camps were raided by the LRA. With the relocation of schools into the camps, some parents gained confidence and sent their children, including girls, to school. Unfortunately, due to meagre resources, the camp 'learning centres' had overwhelming teacher-to-pupil ratios and highly inadequate educational materials.

Apart from the fact that camp schools provided a somewhat safe space for children, they also provided food and water, uniforms (often the only 'good' clothing for the child), and some scholastic materials through the donations of NGOs. Above all, for a population that had experienced terror and hopelessness, the school was a major symbol of hope; it provided a semblance of normality. 
Parental value for education increased with the ability to resettle in safer places. During the insurgency, parents with educated children who were young adults (and whose families were well-to-do) easily relocated to areas outside the war zone, such as Bweyale and Kampala. Those who did not have children to support them remained in the camps with hardly any means of survival. Parent F remarked, "If we had educated children, would we have remained in such a risky place?” Education was associated with the much-desired ability to transcend the geographical limitations of birthplace to access safer spaces during war and post war times.

\section{Problematic Impacts of NGO Support}

The intervention of NGOs was timely. They erected physical infrastructures in IDP camps and elsewhere; paid school fees for children; and provided scholastic materials, uniforms, guidance and counselling, food, and other welfare support. However, NGOs largely used a top-down model that undermined the involvement of parents. Parental involvement in education shrank, with many relinquishing previously taken-for-granted parental responsibilities to school administrators, teachers, and NGOs. Such parents, when invited to school to discuss their child's discipline problems, would make statements such as, 'My child is being paid for by an NGO.' School matters came to be equated to NGO matters with little recognition by parents that they were a vital link in the chain for their child's success.

Parents came to believe that schools taught their children to be 'disrespectful to elders,' a common response to modern, Western education in relation to African traditions. Pupils' seeming lack of respect was linked to new pedagogies introduced by various NGOs that conflicted with traditional African, hierarchically organised models of parent-child relations. Others insisted that the war created new and different identities such as aggression, violent behaviour, and poor discipline, indicated by higher levels of emotional ineptitude among children in reacting to events or statements. Many children had lost their parents, witnessed terrible incidents of rebel attacks on their homes, seen people being murdered, escaped ambushes, or been abducted and managed to escape from the rebels. This complexity of events severely interrupted the previously takenfor-granted 'normal' family routine of upbringing and, according to informants, was a major cause of the strained parent-child, teacher-pupil, and parent-teacher relations. The notion that parents had 'lost control of their children' was a common response to educational challenges noted by parents. 


\section{Alcohol}

An increase in alcohol consumption was noted by many school leaders, mothers, and students during our research. Interestingly, Roberts and colleagues (2011) did not find excessive alcohol disorders among those forcibly displaced in Northern Uganda. Their quantitative study found that 9.5 per cent of men and 1.5 per cent of women surveyed drank three or more times per week. However, community perception of increased drinking was notable in our study. Parent G said,

Some of the parents were not concerned with the welfare of their children, especially the men. Most men in the camps resorted to drinking. So they were not bothered with the welfare and schooling of the children.

Local Leader A in our study stated, "Adults took to serious drinking. Drinking competitions became common where men would compete with women in many bars that were scattered in the camps." Some mothers attributed the drinking expenses of their husbands to their inability to pay school expenses for their children. Roberts et al. (2011) did find significantly higher percentages of men than women who drank regularly. Their bivariate analysis also found higher levels of drinking associated with trauma incidents and high cumulative exposure to trauma.

\section{Government}

According to Tripp (2000), Ugandan parents were of primary importance in supporting schools and education through the formation of Parent-Teacher Associations (PTAs) in the 1960s. These groups were intended to increase communication between parents and teachers. This support actually increased through early decades of civil strife and war. The civil wars of Uganda in the 1970s severely weakened government support of the educational system, with the result that parents took over the funding and management of schools (Hansen \& Twaddle, 1991; Reinikka \& Svensson, 2004). This shift of responsibility gradually increased to the point that, "from the 1980s up until 1996, 90 per cent of school funding came from PTAs, which paid for school maintenance, salaries, educational materials, and furniture" (Tripp, 2000, p. 63). Reinikka and Svensson (2004) stated that "parent-teacher associations (PTA) were the primary decision-makers at the school level, and funding by parents was, on average, the most important source of income” (p. 682). The reduction of government support was problematic, given findings by Dupuy (2008), that 
"government investment in formal education is critical for building peace" (p. 2).

In a bid to ensure re-election, President Museveni introduced Universal Primary Education (UPE) as a government policy in 1996 and abolished PTA fees in 1997 (except in urban schools) (Bategeka \& Okurut, 2005; Nannyonjo, 2007; Tripp, 2000). Parents were not even obliged to contribute to pupils' lunches, as this would lead to the exclusion of the poor. This movement unfortunately linked parent involvement, especially in financial terms, to a sense of being politically incorrect. Low-income parents who were unable to pay school fees initially welcomed the new policy. However, this enthusiasm was short lived. The weak tax base of the country, coupled with a culture of corruption within the ministry and district education offices, could not carry the burden of financing the new policies (Reinikka \& Svensson, 2004). In the absence of a firm foundation, education in many public primary schools deteriorated due to lack of sufficient materials and finances. Teachers, particularly in rural areas, became poorly motivated, as they often did not receive pay for months. Many teachers we interviewed at a well-known secondary school for girls talked about leaving their teaching positions and returning to 'digging' (farming) so they would have food, as they were not receiving pay to buy food. During an interview in 2014, one of our primary teacher participants (Teacher C) told us she had received no pay in three months.

The Inter-Agency Network for Education in Emergency's (2011) analysis of education in fragile states indicated that education can restore the people's trust in the government and strengthen community participation through decentralised structures (p. 13). In the case of Uganda, such benefits did not occur due to governmental promises that were not backed by financial support.

\section{Misconceptions about UPE}

Many parents interpreted the newly hatched program of Universal Primary Education as a shift back to the colonial tradition when such responsibilities belonged to the state. For example, when Western-style schooling was introduced during the British colonial period, the power of parents as teachers of their children (important in indigenous education) was transferred to teachers in formal settings (Musaazi, 2010). After independence, the state continued providing education, with parents only participating in the provision of food and uniforms for their children. This continued up to 1970, during which time civil wars in Uganda reduced state 
allocations for education, and parents came to the aid of schools and teachers through the formation of PTAs, as mentioned.

The UPE program came in the wake of the 1996 political campaigns, at a time when the war in northern Uganda was picking up momentum, and the government sought political control. Many parents interpreted 'free primary education' in terms of withdrawal of parental involvement. According to one of the education officers (Leader B) in our study,

The UPE programme started at a time when many parents in this area required assistance to maintain their children in schools. By then the war had ravaged the area for 10 years and had prevented parents from engaging in money-generating activities.

Thus, the idea of 'free education' and a reduction of parental obligation were welcomed by many, because of increasing poverty. One of the head teachers (Teacher D) reported,

Parents do not come to school to see what their children are doing or learning because under UPE, as they mistakenly understand it, they do not have to pay any money at all. They do not feel responsible for their children's education. They are the government's schools, government's teachers, the government's children.

An education officer (Leader C) also explained,

The UPE programme was misunderstood by parents. Many looked at the programme as a complete package that would not only cater to children's fees, but also include scholastic materials, meals, and uniforms. Thus, any appeal from schools to contribute towards their children's learning was turned down. One of the headmasters called a parents' meeting last term and parents were asked to contribute towards teachers' welfare. This request resulted in a big quarrel. In the end, the majority refused to pay the money, insisting that the government had already provided the school with all the funds needed.

It is important to highlight the sense in which UPE effectively shrank the space parents had previously occupied in the arena of the school. It 
negatively affected the levels of cooperation between administrators of schools with parents, sometimes creating the impression among parents that school administrators, by requesting parental involvement, were simply being corrupt, seeking personal gain at the expense of a barely surviving parental community. Based on Reinikka and Svensson's (2004) findings, beliefs about government corruption were not unfounded. The shrinking of parental involvement consequently rendered the head teachers' task an uphill one. One head teacher (Teacher E) we interviewed reported:

One day, while attending a PTA meeting, it took us three hours to convince the parents to pay an increment of 1500 shillings (50 cents US) to the teachers. The government policies of UPE give opportunities to pupils to attend school without paying school fees. But all the same, many parents do not provide their children with books, pens, or pencils, which, in turn, curtail the enrolment and attendance of many young people.

To counter the negative effects of UPE, teachers and administrators have provided suggestions to increase parental involvement. In an interview, an administrator (Leader D) suggested monthly parent meetings that would include an exhibition of student works and discussion of curriculum. Teacher F suggested that pupil discipline should involve parents rather than teachers only. These suggestions would positively affect the mesosystem level interactions between home and school. There was also a belief by a district official (Leader D) that if the parents were paying for at least some of their children's education, they would be more attuned to the progress of their children.

Although the UPE policy states that parent involvement is crucial on several levels, reducing the importance of PTAs compromised the very notion that the Ministry of Education desired to protect and promote. PTAs remain relatively active in urban areas, but they have declined in rural areas, which encompass most of the villages in northern Uganda.

\section{Post-War Areas of Parent Support and Lack of Support to Education}

Discussions and activities in recent years (our last research phase) indicate a growing interest by community leaders to increase engagement between schools and parents. As one example, a woman participant (Leader E) has created a community-based organisation that explains to rural parents the importance of sending their girls to school. This leader has furthered her work by creating a primary school in a rural area of the Lira 
District, a place in which children formerly had no access to education. Over three years, the school has expanded its grade levels and now has over 100 children enrolled. Parental involvement is an important aspect of this school. As 'payment' for children's school fees, parents often provide bricks to add building structures to the campus. Our research member who conducted the last phase of research twice observed days during which parents attended the school to both watch their children perform songs, dances, and gymnastic routines, but also performed a parent drama as well for their children. On another occasion, she witnessed songs and dances performed at a different school by widows who had taken in some of the school children who had been orphaned.

However, Table 2 shows that $40.8 \%$ of teachers reported that parents did not provide any support to the education of their children. In four parental interviews, this lack of participation was directly linked to their belief that UPE was supposed to provide for all educational needs. Another reason was that parents were busy trying to survive under difficult and abnormal conditions, reclaiming their land and rebuilding homes and jobs.

\section{Table 2: Teachers' responses on the areas of parent support}

\begin{tabular}{|lrr|}
\hline Items & Frequency & Percentage \\
Provision of educational materials & 9 & 18.3 \\
Renovation /building teachers houses & 2 & 4.0 \\
Medical Care & 1 & 2.0 \\
Provide shelter and meals & 1 & 2.0 \\
Attend meetings & 2 & 4.0 \\
Assist with counselling pupils & 12 & 24.5 \\
Enforcing pupils to come to school & 5 & 10.2 \\
No involvement/no support & 20 & 40.8 \\
\hline
\end{tabular}

Nevertheless, some parents provided support in counselling (24.5\%) and provision of educational materials (18.3\%). Another area in which parents supported education was by enforcing school attendance as reported by $10.2 \%$ of the teachers. In relation to guidance, parents provided information about their children. Teacher F explained:

We involve parents in decision making. Parents join hands in prompting discipline. Some parents give us information about their children so that we can help. Parents help us to handle abducted children. 
Only 4.0\% of teachers reported that parents attended meetings. According to Teacher G, parent meetings, where they existed, "tended to be scattered and not focused on issues affecting the quality of pupil performance." Parental withdrawal undermined school meetings as a space for combined efforts between the school and the community to enforce pupil discipline and focused commitment to studies. Many parents took a passer-by posture, describing school-going children as 'no longer respectful,' and therefore 'deviant,' without actively and responsibly engaging issues in meetings.

War years taught many parents that a boy or girl child, once educated, had the capacity to assist family members out of a predicament. Consequently, some parents surrendered their land to schools if there was a need, in addition to working with the school administration and turning up whenever their schools were undergoing an emergency, such as a student strike. Thus, post-war there is a slowly emerging sense of the importance of sending one's children to school.

\section{Discussion}

Living in fear for over two decades in a conflict area corresponds to numerous physical and psychosocial challenges; among them, loss of health, property, family members; mental and physical illnesses; and destruction of social infrastructure. Given that many families lost their land and their livelihoods during the war, poverty was - and remains - a critical issue (Emwanu et al., 2003). Needs for immediate survival often took precedence over parental interest in schooling. In other cases, parents had the desire to send their children, but poverty and fear prevented them. All of these factors also affected child survivors and led to high dropout rates. For boys who dropped out of school, the most common option was life on the streets; for girls, dropout typically ended in early marriage or prostitution (Schlecht, Rowley, \& Babirye, 2013). War contexts brought to the forefront issues that had been relegated to the margins of cultural priorities during the early post-colonial period.

The main research questions of this article concerned areas of parent support to education and explanation for the existing status:

1. What factors have influenced parental involvement in education in Northern Uganda?

2. In what ways might an ecological approach enhance academic achievement? 
Our research showed that parent involvement in the education of their children has declined over time. Although many parents send their children to school, many do not consult teachers on the performance of their children. Based on Epstein and Saunders' (2006) framework, parents in Northern Uganda have a positive attitude towards education of their children. However, communication between home and school and a voluntary spirit are weak, and many parents do not monitor and assist with school-related work at home.

This means the microsystem, the mesosystem, and the exosystem levels of interaction have been unlinked over time (Bronfenbrenner, 1979, 1999). The long-term context of war and need for survival weakened the intimate link between parents and children, resulting in reduced parental support for their children's education. Parent involvement not only signals to children the value of education, but provides them with additional support and creates continuity between their two primary spheres of influence: home and school (Epstein \& Lee, 1995). Lack of parent involvement with the school (mesosystem) indicates to children their parents' lack of interest not only in their schoolwork, but even in themselves as their children. This also means that there is little congruence between a parent's aspirations and the child's educational goals (Smith, 2008). As Epstein (1987) explains, good parent-teacher collaboration leads students to receive consistent messages from home and school about the importance of education, which positively influences their learning and social development. Further, parents who are more involved in their children's education have children who are less atrisk for behavioural and academic problems than children of parents who are not involved (Alvarez-Valdivia, et al, 2012).

Government promises to enhance free public education for Ugandan children created both a reliance on the government and a reduction in personal responsibility for children's education (the exosystem level of influence). Governmental inadequacies to fulfil those promises have reduced Ugandan parents' beliefs in governmental support and left many to feel incapable of maintaining their children's educational aspirations.

There are many factors that affect parental choice to participate in their children's education. In Uganda, low or inadequate parent involvement in post conflict areas can be explained by the perception created by the state from the time school education was introduced by missionaries in the 1890s. These include non-traditional methods of education, elitist preferences, and the perception that with UPE, government would do everything for their children. When Western-style schooling was introduced, the power of parents as teachers of their children (important in 
indigenous education) was removed and placed on teachers. After independence, the state continued providing education, with parents only participating in the provision of food and uniforms for their children. This continued up to 1970. Gee (2011) lists the following as responsible for parent choice to participate in the education of their children: feelings of efficacy, social norms, school outreach, the saliency of the school, and whether the school has been chosen or is simply the default. Thus depending on the situation, there can be a break in the ecological system, particularly the microsystem and mesosystem layers, which, in turn, affects the child.

From 1970-1986, during the Amin era and subsequent wars (Hansen \& Twaddle, 1991; Hansen, 2013), the state weakened, and parents (through PTA) took up the responsibilities of the state including building houses and providing food baskets' for teachers, and paying teacher allowances (Hansen \& Twaddle 1991). In 1986-1996, parents remained in control of education. With the introduction of Universal Primary Education in 1996, the state took over the provision of education. To some parents, the newly hatched program of UPE seemed to indicate the return to complete national provisions for education, a misconception that nevertheless led to parental withdrawal from involvement in the education of their children.

\section{Conclusions and Recommendations}

Overall, the study has shown that numerous factors are responsible for the decline in parental involvement in Northern Uganda. In particular is the misconception that UPE would end their involvement in the education of their children. Protracted war, poverty, and their effects have also affected parent involvement.

As one strategy to improve parent involvement, district officials suggested the resurrection of monthly parent days in which schools would exhibit pupils' various works. In addition they suggested that pupil discipline should involve parents rather than teachers only. These suggestions would positively affect the mesosystem level interactions between home and school. There was also a belief by the district officials that if the parents were paying for at least some of their children's education, they would be more interested in what goes on at school and finding out whether their children are learning or not. Although fees payment would prevent some parents from sending children to school, it was hoped that since parents previously supported education of their children by paying fees, they would still do the same. 
Although parent involvement is currently low, all is not lost given some enthusiasm the parents are beginning to display with regard to their children's education, as noted in the final phase of our research. Years of war trauma decreased the positive microsystem levels of care and encouragement between parents and children that can be increased with assurance of on-going peace in the region. With encouragement from the schools and clear governmental support, parents would participate effectively in the education of their children at the mesosystem level.

Additional recommendations would include respect for traditional methods of schooling, which could be incorporated with the predominant Western system. Consequences of globalisation, in spite of its problems, have most parents convinced that their children will fare better with a Western education. At the same time, parents have been confused and become disengaged as a result of Western policies such as teaching methods and 'free' education.

Although poverty, fear, confusion, and alcoholism were rife, some informants held that these issues alone could not have accounted for the gap between parents and children, teachers and pupils, and parents and teachers. They intimated that the loss of parental involvement in education led to a new identity of the child: a child who felt neglected, not loved or cared for enough by its parents, would soon lose interest in education and come to disrespect teachers. One of the authors found this theme at a 2015 drama performance by school children in Lira. The words of their poem included a warning to parents who drank and did not pay attention to their children and provide them with the opportunity for an education. A repeated refrain was

'Parents, pay attention!'

\section{Bibliography}

Alvarez-Valdivia, I. M., Chavez, K. L., Schneider, B. H., Roberts, J. S., Becalli-Puerta, L. E., Pe'rez-Luja'n, D., Sanz-Martı'nez, Y. A. (2012). Parental involvement and the academic achievement and social functioning of Cuban school children 1-17. http://spi. sagepub.com/

Bategeka, L. \& Okurut, N. (2005). Policy brief 10: Universal primary education Uganda. Inter-Regional Inequality Facility. https://www.odi.org/sites/odi.org.uk/files/odi-assets/publicationsopinion-files/4072.pdf 
Bird, L. (2003). Surviving school education for refugee children from Rwanda 1994 - 1996: UNESCO International Institute for Education Planning.

Bronfenbrenner, U. (1979) The ecology of human development: Experiments by nature and design. Cambridge, MA: Harvard University Press.

Bronfenbrenner, U. (1999). Environments in developmental perspective: Theoretical and operational models. In S. L. Friedman \& D. T. Wachs (Eds.), Measuring environment across the life span: Emerging methods and concepts (pp. 3-28). Washington, DC: American Psychological Association.

Burde, D. (2004). Weak state, strong community? Promoting community participation in post-conflict countries. Current Issues in Comparative Education, 6(2), 73-87.

Davies, L. (2004). Education and conflict: Complexity and chaos. London: Routledge Falmer.

Dolan, C., \& Hoval, L. (2006). Humanitarian protection in Uganda: A Trojan horse? Humanitarian Policy Group. http://www. alnap.org/resource/11198

Dupuy, K. (2008). Education for peace: Building peace and transforming armed conflict through education systems. Save the Children. Oslo, Norway. http://toolkit.ineesite.org/toolkit/INEE cms/uploads/1150/ for_Peace_Building_Peace.pdf

Emwanu, T., Okwi, P. O., Hoogeveen, J. G., \& Kristjanson, P. (2003). Where are the poor? Mapping patterns of well-being in Uganda, 1992 \& 1999. Nairobi: The Regal Press. http://www.ubos.org/ onlinefiles/uploads/ubos/pdf\%20documents/Uganda\%20Poverty\%20 Atlas\%20optimized\%20.pdf

Epstein, J. L. (1987). Toward a theory of family-school connections: Teacher practices and parent involvement. In K. Hurrelmann, F. Kaufmann, \& F. Losel (Eds.), Social intervention: Potential and constraints (pp. 121-136). New York: Degruyter.

Epstein, J. L., \& Lee, S. (1995). National patterns of school and family connections in the middle grades. In B. A. Ryan, G. R. Adams, T. P. Gullotta, R. P. Weissberg, \& R. L. Hampton (Eds.), The familyschool connection: Vol. 2. Theory research and practice (pp. 108154). Thousand Oaks: Sage.

Epstein, J. L., \& Saunders, M. (2006). Prospects for change: Preparing educators for school, family, and community partnerships. Peabody Journal of Education, 81, 81-120 
Ezati, B. A., Ssempala, C., and Ssenkusu, P. (2011). Teacher's perceptions of the affects of young people's war experiences on teaching and learning in Northern Uganda. In Paulson, J. (Ed.), Education, conflict and development (pp. 185-208). Oxford Studies in Comparative Education. Oxford: Symposium Books.

Gee, L. K., (2011). The Nature of Giving Time to Your Child's School Nonprofit and Voluntary Sector Quarterly 40(3) 552- 565. http://nvsq.sagepub.com

Hansen, H. B. \& Twaddle, M. (1991). Uganda now: Between decay and development. $3^{\text {rd }}$ Edition, London: James Curry Ltd.

Hansen, H. B. (2013). Uganda in the 1970s: A decade of paradoxes and ambiguities. Journal of Eastern African Studies, 7(1), 83-103. Doi: 10.1080/17531055.2012/755315.

Higgins, K (2009). Regional inequality and primary education in northern Uganda report. Prepared for the World Development Report Reshaping Economic Geography.

Human Rights Watch (2003). Abducted and abused: Renewed conflict in Northern Uganda. Vol. 15 (12A), http://www.hrw.org/reports /2003/uganda0703/

Human Rights Watch (2005). Uprooted and forgotten: Impunity and human rights abuses in Northern Uganda. https://www.hrw. org/reports/2005/uganda0905/uganda0905.pdf

IASC (2008). Civil-military guidelines and references for complex emergencies. http://www.refworld.org/pdfid/47da82a72.pdf

International Network for Education in Emergencies (INEE) (2010). Minimum standards for education: Preparedness, response, recovery. $\quad$ http://toolkit.ineesite.org/toolkit/INEEcms/uploads/ 1012/INEE_GuideBook_EN_2012\%20LoRes.pdf

International Network for Education in Emergencies (INEE) (2011). Understanding Education's Role in Fragility, A Synthesis of Four Situational Analyses of Education and Fragility: Afghanistan, Bosnia-Herzegovina, Cambodia and Liberia. Paris: IIEP. http://unesdoc.unesco.org/images/0019/001915/191504E.pdf

Kia, B., \& Aceng, E. (2015). "Lira District, then and now”. In McBrien, J. L., \& J. G. Byers (Eds.), Cold water: Women and girls of Lira, Uganda, pp. 25-34. Kampala, Uganda: Fountain Publishers.

Lewis, S. \& Naidoo, J. (2004) "Whose Theory of Participation? School Governance Policy and Practice in South Africa”, Current Issues in Comparative Education, 6, pp. 100-112. 
Lexow, J., \& Ngonzi, B. (2008). Strengthening child protection mechanisms through emergency education support to northern districts of Kitgum and Pader. Education for Protection and Recovery, NORAD collected reviews Norwegian Refugee Council Review \& Appraisal.

Machel, G. (2001). The Impact of war on children. London: UNICEF.

McBrien, J. L., Stewart, J., \& Ezati, B. (in press). Positive youth development and purpose. Contemporary Journal of African Studies.

McBrien, J. L., Ezati, B. A., \& Stewart, J. (2015). Young women and survival in post-war: Experiences of secondary school girls in Uganda. In C. R. Rodriguez, D. Tsikata, \& A. A. Amposo (Eds), Transatlantic feminisms (pp. 213-234). Lanham, MD: Roman \& Littlefield.

McCormac, M., \& Benjamin, J. A. (2008). Education and fragility in Northern Uganda. American Institutes for Research. http://www. equip123.net/docs/E1-Education_Fragility_Uganda.pdf

Musaazi, J. C. (2010). Planning and development in education: African perspectives. London: Routledge.

Muyanda-Mutebi, P. (1996). An analysis of the primary education curriculum in Uganda including a framework for a primary education curriculum renewal. UNESCO report. http://unesdoc. unesco.org/images/0014/001437/143748eo.pdf

Nannyonjo, H. (2007). Education inputs in Uganda: An analysis of factors influencing learning achievement in grade six. Washington, DC: World Bank Publications.

National Curriculum Development Centre Act (1973). http://opm.go.ug /assets/media/resources/261/NATIONAL\%20CURRICULUM\%20D EVELOPMENT\%20CENTRE\%20ACT.pdf

Reinikka, R., \& Svensson, J. (2004). Local capture: Evidence from a central government transfer in Uganda (2004). The Quarterly Journal of Economics, 119(2), pp. 679-705.

Roberts, B., Ocaka, K. F., Browne, J., Oyok, T., \& Sondorp, E. (2011). Alcohol disorder amongst forcibly displaced persons in northern Uganda. Addictive Behaviors, 36(8), pp. 870-873. DOI: 10.1016/j.addbev.2011.03.006

Schlecht, J., Rowley, E., \& Babirye, J. (2013). Early relationships and marriage in conflict and post-conflict settings: Vulnerability of youth in Uganda. Reproductive Health Matters, 21(41), 234-242. Doi: 10.1016/S0968-8080(13)41710-X. 
Smith, M. J. (2008). Right directions, wrong maps college choice low-SES Africans: Understanding the involvement of American parents to enlist them as partners in college choices, Education and Urban Society 41: 171 http://eus.sagepub.com/content /41/2/171

Strauss, A., \& Corbin, J. M. (1990). Basics of qualitative research: Grounded theory procedures and techniques. Thousand Oaks, CA: Sage.

Stewart, J., Kuly, M., Ezati, B., \& McBrien, J. L. (2015). The importance of storytelling for peace-building in post-conflict states. In L. Finley, J. Connors, \& B. Wien (Eds.), Teaching peace through popular culture. Information Age Press.

Stewart, J., McBrien, J. L., \& Ezati, B. (2016, in press). Educational and psychosocial support for children and youth living in post-conflict Uganda. International Journal of Talent Development and Creativity. December, 4(1).

Suzuki, I. (2010). Parental participations and accountability in primary schools in Uganda. Compare, 32(2), 243-259. Doi: 10.1080 /030579022014300.

Tripp, A. M. (2000). Women and politics in Uganda. Madison: University of Wisconsin Press.

Tripp, A. M. (2004). A new look at colonial women: British teachers and activists in Uganda, 1898-1962. Canadian Journal of African Studies, 38 (1), pp. 123-156.

UNICEF (2009). Uganda Progress report for UNICEF's Education in Emergencies and Post-Crisis Transition programme. http://www. educationandtransition.org/wp-content/uploads/2007/04/ugandaprogress-report-2008.pdf

Women's Commission for Refugee Women and Children (2001). Against all Odds. https://womensrefugeecommission.org/ resources/ document $/ 445$

Woolman, D. (2001). Educational reconstruction and post-colonial curriculum development: A comparative study of four African countries. International Education Journal 2(5), 27-46. 